\author{
N. Ibadildin \\ Candidate of Technical Sciences, Associate Professor of the Business and \\ Management Program \\ ibadildin.nurkhat@astanait.edu.kz,orcid.org/0000-0002-6352-8713 \\ Astana IT University, Kazakhstan \\ F. Tolesh \\ Doctor of Education, Associate Professor of the English Language Program \\ f.tolesh@astanait.edu.kz, orcid.org/0000-0003-1018-3261 \\ Astana IT University, Kazakhstan

\section{T. Assylkhanova} \\ Student of ITM 1902 \\ t.assylkhanova@astanait.edu.kz,orcid.org/0000-0002-8119-0429 \\ Astana IT University, Kazakhstan
}

\title{
IMPACT OF THE COVID-19 PANDEMIC ON STUDENTS IN THE REPUBLIC OF KAZAKHSTAN
}

\begin{abstract}
This study presents preliminary results of the impact of the COVID-19 pandemic on the organization of education in universities, the transition to distance learning, the approach of students to the educational process, and their social life during online learning. The analysis shows the relevance of the selected research topic and requires further study in light of the ongoing COVID-19 pandemic. Despite the significant problems caused by the coronavirus, in general, universities have adapted to the current situation. Due to the ongoing mutations of the virus, it is not known how long the pandemic will last, so the ongoing research is important for improving the quality of education in universities in the future. Various techniques were used to collect data based on the current situation in order to reduce the likelihood of contracting the coronavirus. Quantitative and qualitative data were collected from students at various universities through an online survey disseminated through social media platforms. Collecting information took the most time. An online survey was used to collect quantitative data. Based on the qualitative data, interviews were conducted with students who had already completed an online questionnaire. Based on the results obtained, proposals were made to improve the organization of online education, attention was drawn to the need to prepare curricula and training courses for online teaching instructors and psychological support for students from universities in our country. In the future, it is planned to continue research and compare the changes with current indicators. Also, the faculty was not covered, which affects the emotional state of students and therefore requires additional attention.
\end{abstract}

Keywords: COVID-19 pandemic, quarantine, online platforms, higher education, online learning.

\section{Introduction}

The global Covid-19 pandemic was announced in March 2020 [1]. Due to the very high virulence of the infection, the government of Kazakhstan, like many other governments around the world, was forced to introduce quarantine, limiting personal meetings and travel [2]. To date, a total of 406383 confirmed cases and 4211 deaths have been registered in the country, 
and about $15 \%$ of the population is currently vaccinated [3]. Educational institutions were among the first organizations to close after the announcement of quarantine in the country. There are 128 higher educational institutions in Kazakhstan with 624,263 students and 36,307 teachers [4]. Educational organizations had to switch to the so-called "Emergency training" mode [5], switching from full-time classes to distance learning. The universities of Kazakhstan have used various e-learning platforms, the most popular of which are Zoom and MS Teams.

Despite the situation due to the global pandemic [5], such an unexpected transition to mass digitalization of almost the entire education process revealed the weaknesses of the system, the "digital inequality" [6] and the unpreparedness of the people involved. In addition, "online videos, digital content and discussion forums cannot provide a holistic teaching-learning outcome" [6], since learning outcomes are measured not only by the amount of acquired knowledge and skills, and the level of grades. The most important part of higher education is the interaction and communication of students with fellow students and teachers, as well as with the academic environment and the scientific community in general. In addition, the socioeconomic status, personality, interests and academic ability of students significantly affect the effectiveness of courses and curricula [7]. Such differences would be much more difficult to spot during online learning. As a result, students with an innate interest in education suffer noticeably less compared to the "vulnerable group of students," who are much weaker in learning and self-motivation [5].

This situation leads to many difficulties, in particular, students report feelings of depression, stress, anxiety, which are exacerbated by problems with the Internet, a lack of necessary educational equipment and an unfavorable home environment [8]. Understanding the impact of the transition to online learning on the lives of students is a prerequisite for improving their well-being, as well as improving online learning methods and adapting curriculum content to digital learning [9].

The purpose of the article is to try to offer higher education institutions recommendations for adapting curricula and courses to better support and motivate students during distance learning.

2. Literature review and problem statement

All aspects and areas of society, including higher education, have been affected by COVID-19. Coronavirus infection has had a global impact on education in all countries. All states had to urgently introduce online education, but the uneven spread of infection, as well as differences in economic development and other factors, influenced measures taken to change curricula, including higher education. There have been preliminary studies of the transition to online education at the university [10].

Research into the impact of the COVID-19 pandemic on teaching and learning around the world requires further study, existing pedagogical methods and platform for different grade levels of upper secondary, secondary and primary education need to be improved, with "inherently motivated students relatively unaffected in their learning" and "A vulnerable group consisting of pupils who are weak in learning face difficulties" [5].

This is a crisis situation, but inside it there is an opportunity to rethink education. It cannot be said unequivocally that online learning is more effective or not; there are many effective and ineffective programs in both online education and offline education. Educators, online platforms, technology creators, student families, technical support staff, business executives, and property owners are all interested in addressing this question because the answer also has a significant impact on their well-being. Learning outcomes involve more than is usually measured by grades or tests. The acquisition of knowledge and skills is only part of the reasons people go to school or take courses. 
Other reasons may include making friends and being able to connect with other people and sometimes foreign students, adapting to society, developing important personal qualities, and even free meals, which are typical for poor children in public schools. It is well known that students differ greatly as learners in many aspects: academic ability, personality, interests, motivation, and experience. These differences can affect the effectiveness of educational programs, online or offline. When trainees are physically in front of us, these differences can be more obvious than when they are out of sight. "Global and digital competencies have long been considered important opportunities for the 21st century. At the same time, the public wants and needs not training, but education [7].

To assess the complex impact of these measures on students, studies have been carried out in various regions of the world using different research methodologies. Basically, online questionnaires and online interviews were used in connection with the introduced quarantine, as well as the ease of organizing such studies. Several authors conducted online interviews with students to better understand the impact of the adopted restrictions on various aspects of their learning. Some authors combined interviews with questionnaires so that the research provided a more complete and comprehensive picture of the students' well-being. First, let's look at developing countries and how the pandemic affected their higher education system through students' answers to the questions posed. Next, let's compare the research of developing countries with more economically developed regions of the world. Then we will compare the results obtained with a similar study in Kazakhstan and what issues can be highlighted by further research in this direction.

Higher education institutions in Nigeria and around the world have lost many teachers, lecturers and great researchers to the COVID-19 pandemic. These losses will affect the growth and development of educational sectors, especially higher education institutions. It is important to note that the closure of institutions affects not only internal evaluations. In the UK, for example, all exams for major state qualifications - GCSE and A level - have been canceled for all students. Depending on the duration of the quarantine, we have observed similar actions around the world. National school closures as a result of the COVID-19 pandemic in Nigeria and around the world have resulted in severe disruption to student learning; academic disruptions, suspension of exams, cancellation of domestic and international conferences, creating gaps in teaching and learning, and, caused by a shortage of staff in educational institutions as a result of deaths caused by COVID-19 [11].

In Bangladesh, a study was conducted among bachelors studying in the capital city of Dhaka and beyond. Students who study in high school, college, above their bachelor's degree, abroad, or on study leave were considered to deviate from the boundary condition. The data was collected through an online survey from mid-May to June 1, 2020, when this country was in both partial and complete isolation due to the COVID-19 pandemic. To administer the survey, various digital platforms such as Facebook, WhatsApp, Google Classroom and email were used. This study involved 418 university students. Statistical analysis was carried out according to the normal distribution of the data. The majority of the participating students (61.48\%) experienced the strong impact of the restrictive measures taken due to the pandemic. Participants in this survey were concerned about their mental health (47.84\%) because of this situation. The majority of those surveyed attended online classes (69.62\%). Higher education institutions have supported their bachelors through numerous financial and psychological assistance initiatives. Participating students reported mediocre knowledge, learning attitudes and high practice scores. Female students showed better knowledge of theory and practice than male students. "University students have been overlooked in many preparedness and response measures. However, they can play a key role in reducing any type of risk, be it natural disasters or infectious diseases [12]. 
There is a need to further review and evaluate the effectiveness of online learning, which has been done by researchers from Pakistan. An online survey technique was used to collect data on Pakistani higher education students' attitudes towards online learning. A modified version of the 38-item questionnaire by Bernard, Brauer, Abrami and Surkes (2004) was used to assess the effectiveness of online learning. A pilot test of the survey was conducted among students at the National University of Science and Technology (NUST) Pakistan. Undergraduate students made up $58.8 \%(n=64)$ of the study sample, while $49.2 \%(n=62)$ were postgraduate students. Of the 126 students, $7.9 \%(n=10)$ were between the ages of 16 and 20 , while $92.1 \%(n=116)$ were between the ages of 21 and $25.73 \%(n=92)$ reported that they had adequate access to the Internet, $9.5 \%$ reported that they did not have adequate access, and $17.5 \%(n=22)$ reported that they had limited access to the Internet via a mobile phone or a portable device. Most of the university students surveyed expressed doubts about online learning. Lack of access to the Internet, lack of proper interaction and contact between students and teachers, and ineffective technology have been some of the main problems faced by Pakistani university students [13].

The very situation with the pandemic affected the psychological state of the students. Let's start with the example of Pakistan. This study explored how the COVID-19 pandemic and subsequent isolation, quarantine and social distancing measures affected students. More attention was paid to the impact on student mental health, that is, the stress and anxiety level of college and university students, using the Zung Self-rating Anxiety Scale. 494 respondents took part in the study, of which $61 \%$ were girls, and the majority of respondents $(77.3 \%)$ were students in the age group of 19-25 years. Among the respondents, 125 (25.3\%), 45 (9.1\%) and 34 (6.9\%) experienced minimal or moderate, severe and most extreme levels of anxiety, respectively. The most significant stressors were related to online learning, academic performance, completion of the current semester, and uncertainty related to exam dates and next semester status. These results were obtained from a qualitative study of Pakistani student feedback. "Many teachers were also unprepared for the sudden transition to remote online classrooms, thus improvising their duties, leading to numerous assignments for students, which seems to be the main source of stress for most students" [14].

A neighboring country has also tried to assess the impact of isolation due to COVID-19 on undergraduate and graduate students at various colleges and universities in West Bengal, India. Data was collected from May 1 to May 8, 2020 through an online survey. The link to the "Google Forms" questionnaire was received by the students via WhatsApp and email. 232 students provided the requested information. A simple percentage distribution was used to assess the learning level of study participants. During the isolation period, about $70 \%$ of students were involved in e-learning. Most of the students used Android mobile devices to attend eLearning. The students faced a variety of issues such as depression, anxiety, poor internet connection, and an unfavorable learning environment at home. During this pandemic, students from remote areas and marginalized populations generally face enormous research challenges. This study proposes targeted interventions to create a supportive learning space for students from vulnerable sectors of society. Strategies are urgently needed to create a sustainable education system in the state that will develop skills for the employability and productivity of young minds [8].

The sudden closure of university campuses in India, as a social distancing measure to prevent transmission of infection in the community, has shifted face-to-face classes to online learning systems. This has prompted a focus on using eLearning tools and platforms to effectively interact with learners, which may have limitations in accessibility and accessibility for many students. The pandemic has highlighted the shortcomings of the existing higher education system and the need to improve the skills of teachers in the field of digital technologies to 
adapt to the rapidly changing world climate in the field of education. In a post-pandemic situation, the use of e-learning and virtual education can become an integral part of the higher education system. Higher education institutions and universities should plan post-pandemic educational and research strategies to ensure student learning outcomes and educational quality standards [6].

An article was written in the Philippines to encourage other education researchers to also document and provide research evidence of how the current pandemic has changed how education systems work around the world. The dissemination of knowledge begins in educational institutions. Consequently, the educational system, especially higher education, must prioritize literacy in order for the world to skillfully cope with a future possible outbreak of the virus. The following recommendations were made: integrate environment and health courses into the curriculum; strengthen environmental policy and hygiene practices; create online mental health and medical services; align curriculum competencies with expanding teacher training for online learning; to support research efforts, data monitoring and evidencebased practice [15].

Despite different economic developments, students from developed countries also experienced psychological discomfort according to the results of an Australian study. The shift to online learning has had a significant (mostly negative) impact on both the overall learning experience of students in a given country and their psychological well-being. The survey was conducted from May 29 to July 6, 2020. The recruitment of participants was carried out through social networks (Facebook, Instagram, Twitter). 1326 students agreed to participate, 137 could not participate because they were not university students, 399 did not fill out the questionnaire and 3 people completed the questionnaire in less than 4.6 minutes and were therefore excluded from the results. The responses of 787 participants were analyzed. Undergraduate and undergraduate students at university showed increased anxiety when thinking about the future, decreased mental health and overall attitudes than graduate students. That said, concerns about the future were more pronounced among international students than locals, with international students reporting that most of them received more university support for COVID-19 than local students. The most significant indicators of low health are female, lower social status, which was revealed during the analysis of the data. "Strategies specifically tailored to the needs of female students and, in general, students with low social status are urgently needed in order not to aggravate the existing imbalances" [16].

Another developed country that has been affected by the coronavirus crisis and has done research is Italy. As in many cases, an anonymous survey of 34 questions was conducted. In this case, undergraduates and future dentists of the Italian region of Emilia-Romagna took part. 399 students (75\%) out of 532 answered the questions. The Italian authors assessed the psychological impact of COVID-19 on the scale of generalized anxiety disorder-7 (GAD-7). Numerical data were analyzed using analysis of variance (ANOVA), while Pearson's correlation coefficient $(R)$ was calculated to investigate the relationship between quantitative variables. Most of the undergraduates have had problems writing their master's thesis. For more than half of students, online learning has only partially replaced traditional offline classes. The level of fear of contracting COVID-19 during future university activities was positively correlated with the perception of risk associated with clinical training. The results of this survey can be used to teach students more accurate risk assessment [17].

A different approach, involving qualitative research in the form of a podcast interview, was taken at Cambridge. This study uses a new action-driven method: podcasting. The Cambridge researcher used the podcast in his research methodology in the following way: he selected snippets from various episodes of the Cambridge Quaranchats podcast, which were combined into a 45-minute compilation. This episode was then sent to a total of 10 study participants 
who agreed to be interviewed privately. Individual anonymous interviews were conducted with each of the study participants. Each participant was asked to listen to an episode of the compilation of the podcast prior to the interview and take notes of their observations and emerging images while listening to different voices on the podcast that speak of hopes and fears for the future of higher education.

In this way, the podcast snippets served as background sound, awakening the imagination of the participants in response to the podcast they listened to in preparation for the interview. It emerged from the interview that there is no one clear utopian vision of the future, but rather a deeper understanding of the complexity of the transition to online education after the pandemic. While most participants said that an entirely online university was the bleakest outcome they could imagine, a full return to pre-pandemic education is also undesirable. Instead, the utopian future of postcoronial university includes some of the obvious benefits of online education, such as increased levels of freedom and accessibility. Mixed approaches seem to be the most desirable in a utopian future, as noted by the study participants. Most accurately, one of the interviewed students spoke about this. "My dystopian university would be completely online. For me, that would be a dystopia, because I think of myself as a student, I need classroom instruction. I think the universities that charge high prices for online education opportunities are so dystopian, so anti-humanistic, in a way" [18].

According to other authors, the most important pandemic precaution, called "social distancing" or "physical distancing", was aimed at reducing interpersonal contact and thus minimizing community transmission that can rapidly evolve in dense social networks. such as a university campus. To slow the spread of the new coronavirus, many universities in the United States have switched to online education. Now they are faced with the question of whether and how to resume full-time education. This paper uses decryption of data from an average American university to describe three networks that connect students through classes and in the process create the social conditions for the spread of infectious diseases: the university network, the student-only network, and the art colleges network. All three networks are "small worlds" characterized by high clustering and connecting students in different ways. Students from different majors were pooled together for core courses and placement requirements create cross-linking. The incidence of infection declines when large courses of 100 or more students are taught online, but medium-sized courses must also be online. In all simulations, most of the students are connected through several independent paths. Hybrid learning models can reduce, but not eliminate, the possibility of infection. The epidemic, of course, has spread to "small worlds" [19].

One of the most comprehensive studies on this topic, conducted in early 2020, involved 30,383 students from 62 countries. This study found that in conditions of isolation around the world and the transition to online learning, students were most satisfied with the support provided by the faculty and public relations of their universities. Despite the negative aspects of the COVID-19 pandemic, a positive impact was also noted: "in addition to many problems, the pandemic has led to some more positive changes in habits and thinking, such as more attention to personal hygiene, taking care of our own health (quitting smoking, drinking environmentally pure products of local production) and their relatives, especially those from risk groups, more time to go in for sports" [20].

In Kazakhstan, the introduction of online education required some effort from both the state and other stakeholders. Various platforms are used such as Google classroom, Zoom, Google meets, Handouts, Edupage and others. However, despite the ongoing efforts, the transition to distance learning required adaptation on the part of students, parents and teachers. This situation gave impetus to explore new possibilities of digital technologies and search for new sources that could be conveyed to students [21]. 


\section{The purpose and objectives of the study}

The purpose of this study is to develop recommendations for making changes to the concept of higher education in online learning in the context of the COVID-19 pandemic based on quantitative and qualitative analysis in the Republic of Kazakhstan. The objectives of the study are: to study the quality of education, attendance of online classes and socialization of students during the quarantine caused by the COVID-19 pandemic.

\section{Materials and methods}

Quantitative analysis

Sample population

This online study involved 161 undergraduate students studying in various higher education institutions throughout Kazakhstan and abroad.

\section{Data collection and procedure}

The online survey was conducted from 09 March to 19 May 2021 to collect quantitative data. A link to the questionnaire using a "google form" was sent to the students via various social networks such as Telegram, Whatsapp and Instagram. The description of the study and all the possible risks and benefits for the participants were explained in the introduction to the survey. Confidentiality was guaranteed and participants' anonymity was preserved by combining the types of institutions. No other confidential and personal information was collected. A total of 161 participants completed the entire questionnaire. All incomplete attempts were sorted from the dataset. Additionally, four volunteers from among the survey respondents were interviewed.

\section{Data analysis}

Descriptive statistics were carried out to illustrate the main characteristics of the participants. A simple percentage distribution was calculated to assess the type of institution, year of study, employment status, change in average academic performance before and during the pandemic. In addition, several crosstabs and frequency of issues related to online learning and self-isolation were carried out using SPSS Version 21.

\section{Obtained results}

\section{Participant characteristics}

Thanks to the method of disseminating the survey through social networks, we received answers from Kazakhstani students studying in higher educational institutions of other countries. We decided not to delete these responses, as they also live in Kazakhstan in isolation, as other participants entered local universities and undergo a similar distance learning process. To preserve anonymity, we decided to combine all local universities into one group, and international universities into another group called foreign universities (see Table 1).

As you would expect, the majority of the participants (92\%) were enrolled in local universities at the time of the survey (see Table 1). The share of first and second year students was almost the same - about $42 \%$. Before the pandemic, less than $20 \%$ of participants were studying and working; and it was mostly part-time (19\%) and very few (8\%) worked full-time.

More or less noticeable changes occurred in the group of students with the highest average score of $3.5-4$, which decreased slightly during the pandemic from $35 \%$ to $32 \%$, while the share of students with an average score of $2.5-3$ increased from $18 \%$ in 2019 up to $22 \%$ in 2020-2021 None of the students reported taking sabbatical. 
Table 1. Characteristics of study participants $(n=161)$

\begin{tabular}{|c|c|c|}
\hline Characteristics & Distribution (n) & Percent (\%) \\
\hline \multicolumn{3}{|l|}{ University type } \\
\hline Local & 151 & 92 \\
\hline International & 10 & 8 \\
\hline \multicolumn{3}{|l|}{ Year of study } \\
\hline Foundation & 5 & 3 \\
\hline 1 year & 67 & 42 \\
\hline 2 year & 69 & 43 \\
\hline 3 year & 16 & 10 \\
\hline 4 and above & 4 & 2 \\
\hline \multicolumn{3}{|c|}{ Collaborative learning with work before the pandemic } \\
\hline Yes & 31 & 19 \\
\hline No & 130 & 81 \\
\hline \multicolumn{3}{|l|}{ Employment type } \\
\hline Full time & 13 & 8 \\
\hline Part time & 31 & 19 \\
\hline Online & 9 & 6 \\
\hline I study & 108 & 67 \\
\hline \multicolumn{3}{|l|}{ Average grade 2019} \\
\hline $3,5-4$ & 56 & 35 \\
\hline $3-3,5$ & 67 & 42 \\
\hline $2,5-3$ & 29 & 18 \\
\hline $2-2,5$ & 4 & 2 \\
\hline Ниже & 5 & 3 \\
\hline \multicolumn{3}{|l|}{ Average grade 2020} \\
\hline $3,5-4$ & 52 & 32 \\
\hline $3-3,5$ & 69 & 43 \\
\hline $2,5-3$ & 36 & 22 \\
\hline $2-2,5$ & 3 & 2 \\
\hline Lower & 1 & 1 \\
\hline \multicolumn{3}{|l|}{ Academic leave } \\
\hline Yes & 161 & 100 \\
\hline No & 0 & 0 \\
\hline
\end{tabular}

A cross-tabulation of year of study and type of employment shows that second-year students make up the majority in the categories of full-time, part-time and distance work (see Table 2). After one year of study, some of the students could feel confident enough to look for a job, which could be further stimulated by the transition to distance learning. Indeed, the results show that the number of working students doubled during the pandemic (see Tables 3, 4).

More information about this source. For more information, enter the source text

Post a review

Side panels 
Table 2. Year of Study * Type of Employment (Cross Table)

\begin{tabular}{|l|c|c|c|c|c|}
\hline \multirow{2}{*}{ Year of study } & \multicolumn{5}{c|}{ Employment } \\
\multirow{2}{*}{ Foundation } & Full time & Part time & Online & Study & \\
\hline 1-year & 1 & 0 & 1 & 3 & 5 \\
\hline 2-year & 3 & 13 & 3 & 48 & 67 \\
\hline 3-year & 7 & 14 & 5 & 43 & 69 \\
\hline 4-year and above & 2 & 4 & 0 & 10 & 16 \\
\hline Total & 0 & 0 & 0 & 4 & 4 \\
\hline
\end{tabular}

A comparison of attitudes towards online learning with a mix of study and work before and during the pandemic shows that the majority of students were rather neutral about online learning, both before and during isolation. However, as expected, during online learning more students began to work, and as a result, their number with a positive attitude towards him increased, as well as people with a very negative one (see Tables 3, 4).

Table 3. Collaborative research with work before the pandemic * Attitudes towards online learning (Cross Table)

\begin{tabular}{|l|c|c|c|c|c|c|c|}
\hline \multirow{2}{*}{ Question } & \multirow{2}{*}{ Answer } & \multicolumn{5}{|c|}{ Attitude towards online learning } & \multirow{2}{*}{\begin{tabular}{c} 
Total \\
\cline { 3 - 8 }
\end{tabular}} \\
\cline { 3 - 8 } & & Negative & So-so & Neutral & $\begin{array}{c}\text { Somewhat } \\
\text { positive }\end{array}$ & $\begin{array}{c}\text { Very } \\
\text { positive }\end{array}$ & 31 \\
\hline $\begin{array}{l}\text { Collaborative learning with } \\
\text { work before the pandemic }\end{array}$ & Yes & 5 & 4 & 13 & 5 & 26 & 130 \\
\hline Total & 161 & 19 & 18 & 64 & 31 & 29 & 161 \\
\hline
\end{tabular}

Table 4. Collaborative research with work during a pandemic * Attitudes towards online learning (Cross Table)

\begin{tabular}{|c|c|c|c|c|c|c|c|}
\hline \multirow[b]{2}{*}{ Question } & \multirow[b]{2}{*}{ Answer } & \multicolumn{5}{|c|}{ Attitude towards online learning } & \multirow[b]{2}{*}{ Total } \\
\hline & & Negative & So-so & Neutral & $\begin{array}{l}\text { Somewhat } \\
\text { positive }\end{array}$ & $\begin{array}{c}\text { Very } \\
\text { positive }\end{array}$ & \\
\hline \multirow{2}{*}{$\begin{array}{l}\text { Collaborative learning with } \\
\text { work before the pandemic }\end{array}$} & Yes & 11 & 5 & 22 & 12 & 11 & 61 \\
\hline & No & 8 & 13 & 42 & 19 & 18 & 100 \\
\hline Total & 161 & 19 & 18 & 64 & 31 & 29 & 161 \\
\hline
\end{tabular}

Increased student employment will undoubtedly affect their attendance. Indeed, the number of students regularly attending classes fell from $65 \%$ before the pandemic to $49 \%$ during the pandemic, while the percentage of rarely attending classes, and sometimes even increased from $2.5 \%$ to $8 \%$ and from $9 \%$ to $17 \%$ respectively. The descriptive statistics in Table 5 illustrate the change in average class attendance before and during the pandemic from 4.36 to 4.05 . Decreased attendance may also be associated with worsening student health. Participants were asked about their general well-being, which had dropped significantly (average during offline learning 3.91; average during distance learning 3.57) (see Table 5). 
Table 5. Descriptive statistics

\begin{tabular}{|l|c|c|c|c|c|}
\hline \multicolumn{1}{|c|}{ Questions } & N & Minimum & Maximum & Average & Standard deviation \\
\hline Attendance before Covid19 & 161 & 1 & 5 & 4,36 & 1,076 \\
\hline Attendance during Covid19 & 161 & 1 & 5 & 4,05 & 1,150 \\
\hline $\begin{array}{l}\text { The general well-being of students } \\
\text { during offline learning }\end{array}$ & 161 & 1 & 5 & 3,91 & 1,137 \\
\hline $\begin{array}{l}\text { General well-being of students } \\
\text { during distance learning }\end{array}$ & 161 & 1 & 5 & 3,57 & 1,219 \\
\hline Cheating during a pandemic & 161 & 1 & 5 & 2,94 & 1,298 \\
\hline Cheating before a pandemic & 161 & 1 & 5 & 2,04 & 0,983 \\
\hline Valid N (by list) & 161 & & & & \\
\hline
\end{tabular}

Another impact of the pandemic on higher education is the increase in student cheating, which is also true for our participants (Pre-Pandemic Average 2.04; Pandemic Average 2.94). The results show that the proportion of students who never and rarely cheated dropped significantly from $34 \%$ to $17 \%$ and from $37 \%$ to $23 \%$, respectively. At the same time, the percentage of students who often and always cheat has grown sharply from $7 \%$ to $23 \%$ and from $4 \%$ to $14 \%$, respectively (see Table 6 ).

Table 6. Cheating students before and during a pandemic

\begin{tabular}{|l|c|c|c|c|}
\hline \multirow{2}{*}{ Answers } & \multicolumn{2}{|c|}{ Cheating before a pandemic } & \multicolumn{2}{c|}{ Cheating before a pandemic } \\
\cline { 2 - 5 } & Frequency & Percent & Frequency & Percent \\
\hline Never & 55 & 34 & 27 & 17 \\
\hline Seldom & 59 & 37 & 37 & 23 \\
\hline Sometimes & 36 & 22 & 38 & 24 \\
\hline Often & 7 & 4 & 37 & 23 \\
\hline Always & 4 & 2 & 32 & 14 \\
\hline Total & 161 & 100 & 161 & 100 \\
\hline
\end{tabular}

According to the survey results (see Table 7), the most common problems that students faced while studying online were poor internet connectivity, environmental distractions, and lack of motivation. Interestingly, only $2 \%$ of participants cited the lack of internet-connected devices as a problem. Problems with the university website, the unexpected transition to an online learning format and time management were mentioned equally at $11 \%$, and lack of time was mentioned a little more often (13\%).

Table 7. What problems did you face during online learning?

\begin{tabular}{|l|c|c|}
\hline \multicolumn{1}{|c|}{ Answers } & frequency & percent \\
\hline Poor internet connection & 95 & 17 \\
\hline Breaks during classes & 96 & 18 \\
\hline University website did not work & 60 & 11 \\
\hline Fast transition to a new training format & 59 & 11 \\
\hline Lack of time & 70 & 13 \\
\hline Lack of motivation & 97 & 18 \\
\hline General & 61 & 11 \\
\hline Time management & 9 & 2 \\
\hline Lack of a device for online learning & 547 & 100 \\
\hline Total & & \\
\hline
\end{tabular}


Given the importance of communication and interaction in the learning process, there was a separate question in the questionnaire about the impact of students' self-isolation from their peers. An equal percentage of respondents reported that they had lost interest in learning and felt pressured by an increase in homework. Very often, distance learning includes in-depth self-education, which is carried out in the form of homework, which some students struggle with without the daily help of their peers. Thus, $22 \%$ of students reported that they were unhappy with the lack of personal communication with their peers (see Table 8). In addition, $20 \%$ stated that they felt a lack of general communication, which could mean that, despite the various interactive software available, students were unable to establish a satisfactory level of communication with their peers. Very few participants claimed that self-isolation did not affect them.

Table 8. How has self-isolation from peers affected you?

\begin{tabular}{|l|c|c|}
\hline \multicolumn{1}{|c|}{ Answers } & Frequency & Percent \\
\hline I have lost interest in learning & 74 & 23 \\
\hline My interest in learning has increased & 12 & 4 \\
\hline I felt pressure from the increased amount of homework & 73 & 23 \\
\hline Dissatisfied with the lack of personal meetings & 69 & 22 \\
\hline I lacked communication & 64 & 20 \\
\hline Hasn't influenced in any way & 27 & 8 \\
\hline Total & 319 & 100 \\
\hline
\end{tabular}

Overall, quantitative data indicate that more students started working part-time during the pandemic, resulting in lower attendance and more cheating to cope with the increased amount of homework. They were rather dissatisfied with the lack of interaction with peers and poor Internet connections, as well as the need to isolate themselves in an environment that is not conducive to a productive learning process.

Qualitative analysis

There is still debate about the definition and practicality of qualitative analysis [22]. However, in this article, we have used qualitative analysis to complement and improve the interpretation of the online questionnaire. Five interviews were conducted concurrently with the collection of quantitative data. All interviews were conducted online in Microsoft Teams due to the convenience and limitations of COVID-19. They began on March 16, 2021 and ended on March 18, 2021. A total of five interviews were conducted in Russian with survey participants from three different Kazakhstani universities. One of the students was from the foundation, and four others were second-year students. All students were from large cities of Kazakhstan and did not experience any difficulties with connecting to the Internet. All interviews have been transcribed for interpretation purposes. Participants had the opportunity to elaborate on various aspects of their experience. Due to the pandemic situation, the participants' consent was obtained orally. Moreover, the students conducted interviews to minimize the generation gap.

\section{Lack of communication}

Due to the unexpected quarantine of COVID-19, universities and students took time to adapt to the new reality, not only technically, but also psychologically in terms of socialization. People relied more on family members and classmates. For a fundamental student, everything was more difficult due to the fact that she did not know her classmates well at the beginning of the school year. The student of the foundation said: "During online communication, communication is canceled. Especially in the beginning, when you were quarantined at home 
altogether. I would not say that even among the courses I take, I tried to meet someone new. In order to somehow stay in touch, we have groups on Telegram, where we usually share with each other something like "Don't forget the exam today!"... But I really didn't even try to get to know any of these people. "Social life became limited due to severe restrictions during the first wave of coronavirus infection.

\section{Time management and self-discipline}

Students needed to change their learning style by spending more time on independent study and better preparing for class. The lack of interaction with teachers was compensated by watching videos of lectures, reading textbooks and searching for additional information on the Internet. Zhannur noted in her interview: "Before the pandemic, I tried to write down everything the teacher said, but now l'm just doing self-study (self-study). I study myself, I look for information myself. "If a student is not prepared for independent study, it will be difficult for him to keep up with more disciplined peers.

\section{Positive effects}

Despite the many inconveniences of quarantine, some participants noted the positive effects of quarantine, such as better scheduling of activities and more time to take care of themselves. "There are definitely advantages. Considering that during offline training there is not much time for the development of some hobbies and so on. Well, at home in this regard, it will still be quieter. You yourself manage your time. "These positive effects need to be analyzed more carefully, as there is still no certainty about the end of the pandemic situation. Thus, education will become a hybrid of face-to-face and online learning.

In general, the interviews were consistent with the results of the quantitative analysis, but at the same time showed some limitations of the qualitative research.6.

Students try to find work after their first year of study, and online education has given them more flexibility in finding work, as evidenced by the increase in student employment. The pandemic was not the only reason for looking for a job, but it provided additional motivation for students. This activity was one of the reasons for the decline in attendance for online lessons.

The transition from face-to-face training to online training is not as easy as it might seem. This effect is accentuated by increased cheating. This is evident from the quantitative analysis, in which the participants were anonymous. The interview did not reveal such a correlation, which can be explained by different factors or their combination. Distance learning is challenging for students, but not all of them want to spend more resources and maintain a high GPA.

Spending more time with the various devices required for online learning led to a decrease in the level of communication between participants. Survey and interview data confirm this result. Lack of personal interaction with teachers and peers reduced student motivation and affected the GPA and psychological well-being of students. Participants interacted more with family members than with classmates. All of these reasons have diminished the value of a university degree related not only to grades, but also to networking and peer interactions.

This study looks at one side of the participants, namely the students. However, it is worth examining the impact of COVID-19 on trainers. They can provide a more complete picture of the educational process. Some of them require special preparation for online classes to keep students more focused on lectures and practical sessions. Moreover, none of the participants mentioned psychological assistance from universities, which may be a bad sign that the university is not ready for such a situation. In addition, the next academic year can restructure and organize the survey and interviews to conduct longitudinal research. 


\section{Conclusions}

The results of the qualitative and quantitative analysis of the data allow us to draw several conclusions.

1. The COVID-19 pandemic has become a serious test for all universities of the Republic of Kazakhstan and students.

2. Online learning motivated students to find work, which was the reason for the decline in class attendance and communication skills.

3. Motivation for learning has decreased due to the lack of personal contacts of students with teachers and fellow students.

4. There is a need for special training of teachers in online classes to increase the motivation of students for university education.

5. In extreme learning conditions, it is necessary to strengthen, raise to a new level psychological assistance to students.

6. A positive lesson of the COVID-19 pandemic was the realization of the need to reassess and adapt teaching at universities by including online disciplines with the creation of a hybrid model of education in universities in Kazakhstan.

\section{Acknowledgments}

The authors of the article express their gratitude to the senior lecturer of AITU D. Kumarbekov for help in writing the article, as well as to all university students who took part in the interview and online survey.

\section{Reference}

1. World Health Organization. (2020). WHO Coronavirus Disease (COVID-19) Dashboardl WHO Coronavirus Disease (COVID-19) Dashboard [Internet] https://covid19. who. int/ [cited 2020 Sep 3]. Available from: [Google Scholar].

2. Указ Президента Республики Казахстан от 15 марта 2020 года № 285 «О введении чрезвычайного положения в Республике Казахстан». Информационная система ПАРАГРАФ. (2020). https:// online.zakon.kz/Document/?doc_id=32648341.

3. Ситуация с коронавирусом официально. (2021). https://www.coronavirus2020.kz/.

4. gov.kz. (2021). https://www.gov.kz/memleket/entities/edu/activities/272?lang=ru.

5. Pokhrel, S., \& Chhetri, R. (2021). A literature review on impact of COVID-19 pandemic on teaching and learning.HigherEducationfortheFuture,8(1),133-141.https://doi.org/10.1177/2347631120983481

6. Rashid, S., \& Yadav, S. S. (2020). Impact of Covid-19 pandemic on higher education and research. Indian Journal of Human Development, 14(2), 340-343. https://doi.org/10.1177/0973703020946700

7. Zhao, Y. (2020). Tofu Is Not Cheese: rethinking education amid the COVID-19 pandemic. https://doi. org/10.1177/2096531120928082

8. Kapasia, N., Paul, P., Roy, A., Saha,J., Zaveri, A., Mallick, R.,... \& Chouhan, P. (2020). Impact of lockdown on learning status of undergraduate and postgraduate students during COVID-19 pandemic in West Bengal, India. Children and Youth Services Review, 116, 105194. https://doi.org/10.1016/j. childyouth.2020.105194

9. Salykova, L., Ibadildin, N., \& Borashova, S. (2021, April). Analysis of Educational Transformation at Astana IT University (AITU). In 2021 IEEE International Conference on Smart Information Systems and Technologies (SIST) (pp. 1-4). IEEE.

10. ИбаДИЛЬДИН, Н.А. (2020). ПРОМЕЖУТОЧНЫЕ РЕЗУЛЬТАТЫ АНАЛИЗА ПЕРЕХОДА НА ПОЛНОЕ ОНЛАЙН ОБУЧЕНИЕ В КАЗАХСТАНЕ НА ПРИМЕPЕ ASTANA IT UNIVERSITY. ВестнИк КазахСКого национального медицинского университета, (4), 526-528. https://kaznmu.kz/press/wp-content/ uploads/2021/01/\%D0\%92\%D0\%B5\%D1\%81\%D1\%82\%D0\%BD\%D0\%B8\%D0\%BA-\%D0\%9A\%D 0\%B0\%D0\%B7\%D0\%9D\%D0\%9C\%D0\%A3-\%E2\%84\%964-2020.pdf 
11.Jacob, O.N., Abigeal, I., \& Lydia, A.E. (2020). Impact of COVID-19 on the higher institutions development in Nigeria. Electronic Research Journal of Social Sciences and Humanities, 2(2), 126-135. http://www.eresearchjournal.com/wp-content/uploads/2020/04/0-Impact-of-COVID.pdf

12. Rahman, M.M., Khan, S.J., Sakib, M.S., Halim, M.A., Rahman, M.M., Asikunnaby, \& Jhinuk, J.M. (2021). COVID-19 responses among university students of Bangladesh: Assessment of status and individual view toward COVID-19. Journal of Human Behavior in the Social Environment, 31(1-4), 512-531. https://doi.org/10.1080/10911359.2020.1822978

13. Adnan, M., \& Anwar, K. (2020). Online Learning amid the COVID-19 Pandemic: Students' Perspectives. Online Submission, 2(1), 45-51. https://doi.org/10.33902/JPSP. 2020261309

14. Baloch, G.M., Sundarasen, S., Chinna, K., Nurunnabi, M., Kamaludin, K., Khoshaim, H.B.,... \& AlSukayt, A. (2021). COVID-19: exploring impacts of the pandemic and lockdown on mental health of Pakistani students. PeerJ, 9, e10612. https://doi.org/10.7717/peerj.10612

15. Toquero, C. M. (2020). Challenges and opportunities for higher education amid the COVID-19 pandemic: The Philippine context. Pedagogical Research, 5(4). https://doi.org/10.29333/pr/7947

16. Dodd, R. H., Dadaczynski, K., Okan, O., McCaffery, K. J., \& Pickles, K. (2021). Psychological wellbeing and academic experience of University students in Australia during COVID-19. International Journal of Environmental Research and Public Health, 18(3), 866. https://doi.org/10.3390/ijerph18030866

17. Generali, L., Iani, C., Macaluso, G.M., Montebugnoli, L., Siciliani, G., \& Consolo, U. (2020). The perceived impact of the COVID-19 pandemic on dental undergraduate students in the Italian region of Emilia-Romagna. European Journal of Dental Education. https://doi.org/10.1111/eje.12640

18. Eringfeld, S. (2021). Higher education and its post-coronial future: utopian hopes and dystopian fears at Cambridge University during Covid-19. Studies in Higher Education, 46(1), 146-157. https:// doi.org/10.1080/03075079.2020.1859681

19. Weeden, K. A., \& Cornwell, B. (2020). The small-world network of college classes: implications for epidemic spread on a university campus. Sociological science, 7, 222-241. https://doi.org/10.15195/ v7.a9

20. Aristovnik, A., Keržič, D., Ravšelj, D., Tomaževič, N., \& Umek, L. (2020). Impacts of the COVID-19 pandemic on life of higher education students: A global perspective. Sustainability, 12(20), 8438. https://doi.org/10.3390/su12208438

21. Bektursynova, A., \& Sarsengaliyeva, B. (2020, June). Impact of terrible pandemic COVID-19 on Kazakhstani education and it's outcome. In Proceedings of International Young Scholars Workshop (Vol. 9). https://doi.org/10.47344/iysw.v9i0.225

22. Aspers, P., \& Corte, U. (2019). What is qualitative in qualitative research. Qualitative sociology, 42(2), 139-160. https://doi.org/10.1007/s11133-019-9413-7 